\title{
The Effect of Work Motivation and Compensation on the Performance of Local Government Employees with Job Satisfaction as an Intervening Variable: A Study on the Regional Government of Bantul Regency
}

\author{
Afrizal Tahar ${ }^{1 *}$, Anja Astia Yonanda ${ }^{2}$
}

\author{
${ }^{1,2}$ Department of Accounting, Faculty of Economy and Business, Universitas Muhammadiyah Yogyakarta, Indonesia \\ *Corresponding author. Email: afrizal@umy.ac.id
}

\begin{abstract}
Regarding the enactment of Government Regulation No. 30 of 2019 concerning performance appraisal, it turned out that several government organizations in the Bantul Regency government still received bad ratings in terms of performance appraisals. From the evaluation results conducted by the National Civil Service Agency through the Directorate of State Civil Apparatus performance, data obtained that 3.33\% of government agencies were very good, $35 \%$ of government agencies were good, $50 \%$ of government agencies were considered adequate, and $11.7 \%$ of government agencies were deemed poor in implementing employee performance management. Along with that research and based on previous research on employees in several regional apparatus organizations in Bantul Regency, it was stated that these employees did not feel any job satisfaction due to the disproportionate compensation they received, which would affect their performance. Therefore, this study aims to determine the effect of work motivation and compensation on the performance of local government employees with job satisfaction as an intervening variable. The samples involved were local government employees of Bantul Regency, consisting of agency, service, and sub-districts in Bantul. This study employed the convenience sampling method. The type of data used in this study was primary data. Based on the questionnaire distribution, 121 respondents were obtained, but only 120 samples could be processed. The results revealed that work motivation and job satisfaction positively affected the performance of local government employees. However, compensation did not affect local government performance. Motivation and compensation also did not affect local government performance through the intervening variable of job satisfaction. Nevertheless, this research's limitation is that the research object was only carried out in Bantul Regency regional apparatus organizations, and not all regional apparatus organizations allowed research to be conducted due to the COVID-19 pandemic.
\end{abstract}

\section{Keywords: Work Motivation, Compensation, Local Government Employee Performance, Job Satisfaction}

\section{INTRODUCTION}

Implementation of Law No. 32 of 2004 and Law No. 25 of 1999 has made local government a pillar of regional autonomy. This statement is included in the general explanation of Law No. 22 of 1999, elucidating the granting of regional or district and city autonomy authority based on the decentralization principle in the form of real, broad, and responsible autonomy. With the existence of the laws, it can help clarify and further strengthen the form of autonomy, which will be further developed. Here, autonomy does not only provide and carry out government responsibilities but also provides an overview or explanation to the government regarding the duties and authorities in managing and regulating all things in government. It makes the local government better if it can improve and further upgrade its performance to carry out all administrative activities or government obligations or services to the community. However, without making improvements and enhancing the performance to the public, it is difficult to say that the autonomy policy's benefits have been received by the citizens. It can also signify that matters affecting the quality level in implementing government obligations and service activities to the community are crucial for the regional autonomy development now.

For this reason, to improve the quality of local government services to the community, good government management is demanded. It leads to increased efficiency and effectiveness of high performance, service quality improvement, and work method improvement, overcoming various disturbances or obstacles. In addition, the delegation of authority or responsibility should be adjusted to the arrangements for the resources' distribution and utilization, which are national and equitable, and take into account the regional and central financial balance (Sutrisno, 2013). In this case, performance can be interpreted as the result of work or something comprehensive and better if it is more upgraded, both in terms of personal, organizational, and even certain groups. The performance produced by employees can be observed from several aspects, including quality, quantity, time spent working, and collaborative activities to achieve goals that have been previously approved by the corporate body or company (Sutrisno, 2013). According to Lloyd \& Hessel (2010), in improving employee performance, several factors influence it: compensation, leadership style, job satisfaction, motivation, discipline, organizational culture, 
work environment, and organizational commitment. However, this research prioritizes compensation, work motivation, and job satisfaction.

The first factor that can affect a person's performance is compensation. In accordance with what Veithzal (2007) stated, compensation is a right received by employees, functioning to replace the employees' contribution or services to the company, which are further grouped into two: direct compensation and indirect compensation. Direct compensation, for example, is the payment of salaries and holiday allowances for employees. Meanwhile, indirect compensation comprises insurance, work uniform facilities, etc.

The second factor impacting a person's performance is work motivation. Motivation can be inferred as a force that can increase an individual's behavior according to direction and purpose. In other words, it is a determining factor for the success of a corporate body or local government.

The last factor in this research is job satisfaction. Job satisfaction is personal/individual. Each individual has a satisfaction level in accordance with the assessment process or guidelines contained in each of them. It means that if an individual's needs always increase, he will always try to get something he wants to satisfy his needs according to his abilities. Meanwhile, as Devi (2009) asserted, job satisfaction is a person's behavior regarding his work. Job satisfaction can prove the similarity between an individual's desires with the rewards applied to his work.

In connection with the previous description, the objects studied in this study were all regional apparatus organizations (OPD) in Bantul Regency. Regional apparatus organizations consisted of several agencies, offices, and sub-districts in the Bantul Regency area, listed in Regional Regulation no. 12 2016 concerning the establishment of regional service organizations within the Bantul Regency Government. Regional apparatus organizations are organizations or institutions in regional governments responsible to regional heads in administering regional government. However, regarding the enactment of Government Regulation No. 30 of 2019 concerning performance appraisal, several government agencies in Bantul Regency apparently still received bad ratings in terms of performance appraisal.

The evaluation results conducted by the National Civil Service Agency through the Directorate of State Civil Apparatus performance revealed that $3.33 \%$ of government agencies were very good, $25 \%$ of government agencies were good, $50 \%$ of government agencies were considered adequate, and $11.7 \%$ of government agencies were deemed poor in implementing employee performance management. Along with that research and reinforced by several previous studies on employees at several regional organizations in Bantul Regency, it was uncovered that some employees did not feel any job satisfaction because it was not comparable to the compensation they received. If the compensation provided by the government is not as expected, then it can affect an employee's work motivation that can be an encouragement to achieve something so that job satisfaction and good performance can also be accomplished.
Moreover, the difference between this research and previous research lies in the sampling, theory, research object, and research time.

\section{LITERATURE REVIEW HYPOTHESES DEVELOPMENT}

AND

Attribution theory explains a person's behavior. Meanwhile, motivation itself is a form of attitude or behavior of an employee in dealing with situations or work environment around. Motivation is also a condition that moves an employee to achieve the organization's goals.

In this case, the human factor can be one that must receive attention. The role of an individual in a company or organization is vital to achieve and even improve the goals set in the company. Hence, employee performance can be used as a measure in determining the company's effectiveness and efficiency.

The strongest (dominant) employee performance usually appears due to mental readiness and individual motivation to trigger achievement, which is useful for getting everything desired. If each individual gets a high motivation level, it can affect the employee performance level, as obtained from research (Fachreza et al., 2018).

In a study conducted by Sidanti (2015), it was found that work motivation had a positive effect on the performance of civil servants in the DPRD secretariat of Madiun Regency. Dharma research (2018) also showed that work motivation significantly affected performance. In addition, in a study carried out by Martini \& Sarmawa (2019), when viewed in the data analysis results, motivation had a significant positive impact on employee performance.

Based on the theory and previous research above, the following hypothesis could be formulated:

$\mathrm{H}_{1}$ : Work motivation has a positive effect on the performance of local government employees.

On the other hand, the compensation provided for each employee will make each individual motivated to do every job that is his duty to the best of his ability. In theory $\mathrm{Y}$ definition, an employee with a theory $\mathrm{Y}$ type will work independently without orders or supervision from his superiors because he likes the job. It is closely related to local government compensation and performance. If the compensation given follows the employees' wishes, they will undoubtedly be more enthusiastic about working, even for a more extended period.

In Widyantara \& Ardana's (2015) research, compensation can be referred to as a contribution from the company or organization given to employees, meaning that the compensation given would certainly significantly improve each employee's performance. Further, Primananda \& Djastuti's (2015) research also argued that the compensation provision could significantly increase employee performance. In addition, all income in the form of money or goods, directly or indirectly, received by each employee can also be said to be compensation.

Any compensation received by employees should be in proportion to the work done by them. Mangkunegara (2003) concluded in his research that the compensation provided to each employee, in general, greatly influenced the level of job 
satisfaction, work motivation, and work results. Therefore, each employee will improve their performance as expected because of the higher compensation. Besides, Ramli's (2019) research found that compensation had a positive and significant effect on employee performance. In conclusion, compensation provided a positive and significant impact on employee performance, as found in a study carried out by Sumiati (2018).

Based on the theory and previous research, the following hypothesis could be proposed:

$\mathrm{H}_{2}$ : Compensation has a positive effect on the performance of local government employees.

In attribution theory, the study of job satisfaction focuses on employee behavior towards work. Job satisfaction, according to Robbins (1996), refers to the general attitude of an individual to his job. Meanwhile, Locke (1976) defines it comprehensively as a state of "comfort" or positive emotions of an individual as a result of a work assessment or work experience. Job satisfaction is also an employee's perception of how his job provides something considered crucial, generally accepted as essential in the field of behavior in the organization (Mitchell and Larson, 1987).

Satisfaction will undoubtedly affect each employee's performance. Employee job satisfaction can occur in line with what is expected and received. A study conducted by Kurniawan (2013) stated that the condition of job satisfaction or dissatisfaction could influence each employee's performance. In addition, Putrana et al.'s (2016) research denoted that job satisfaction, including salary, peer attitudes, and leadership, significantly impacted employee performance.

Moreover, Yanuarti \& W (2014) carried out research that had the same conclusion as previous research that job satisfaction affected teacher performance. A study by et al. (2018) also showed that job satisfaction positively affected employee performance. Ramli (2019) also obtained the same conclusion, stating that job satisfaction positively and significantly impacted employee performance. Also, research conducted by Husein \& Hanifah (2019) resulted in job satisfaction having a positive effect on employee performance.

Based on the theory and previous research above, the following hypothesis was stated:

$\mathrm{H}_{3}$ : Job satisfaction has a positive effect on the performance of local government employees.

Furthermore, theory $\mathrm{Y}$ assumes that all people who serve in institutions or organizations work with motivation from within themselves and are willing to take responsibility for their jobs. It relates to each individual's work motivation, which will affect the individual's job satisfaction level, certainly impacting each individual's performance.

In this case, work motivation is a concept that describes something that every employee has, which can direct behavior towards that individual. Work motivation can also trigger an encouragement or work spirit to achieve job satisfaction (Suharto, 2012). According to Suwardi \& Utomo's (2011) research, employee motivation and job satisfaction could improve organization performance. A study carried out by Stringer et al. (2011) also said that motivation influenced wages and job satisfaction. The job satisfaction obtained can then trigger an increase in performance in each employee.

In Ayundasari et al.'s (2017) research, it was concluded that motivation affected job satisfaction, job satisfaction affected employee performance, and motivation affected employee performance mediated by job satisfaction. In addition, Pancasila et al. (2020) conducted a study with the result that work motivation positively and significantly impacted job satisfaction so that it could mediate work motivation on employee performance. Besides, a study done by et al. (2018) found that work motivation significantly affected job satisfaction and employee performance. Job satisfaction also fully mediated work motivation on employee performance.

Based on the theory and previous research, this hypothesis could be put forward:

$\mathrm{H}_{4}$ : Work motivation has a positive effect on the performance of local government employees through job satisfaction.

Once again, in the attribution theory covering an essential perceptual process as it forms a causal relationship, compensation is undoubtedly associated with personal satisfaction that can develop work motivation, improving performance.

Dessler (2017) described compensation as all forms of remuneration or rewards that flow to an employee appearing in each individual. The compensation provision is expected to motivate every employee to work enthusiastically. If employees are enthusiastic about work, the work performance will also increase; thus, the employee can achieve a sense of satisfaction in the work he does.

Meanwhile, according to Handoko (2011), compensation can be said as everything employees receive as a reward for them. Compensation is what employees receive in exchange for their contribution to an organization or company. Every employee, who is appropriately and fairly compensated, will feel satisfied, which can trigger him to do his job better.

Supiyanto (2015) conducted a study that concluded that compensation and job satisfaction positively related to performance. Hidayah \& Aisyah (2016) also drew the same conclusion as previous studies that compensation and job satisfaction had a significant relationship with employee performance. In addition, a study conducted by Fernanda \& Sagoro (2016) concluded that compensation and job satisfaction could have a positive effect on employee performance. Prior research conducted by Ramli (2019) also found that compensation positively and significantly impacted employee performance and job satisfaction. The same result was also revealed by Sumiati (2018), stating that compensation showed a positive influence on employee performance.

Based on the theory and previous research above, the hypothesis is:

$\mathrm{H}_{5}$ : Compensation has a positive effect on the performance of local government employees through job satisfaction. 


\section{RESEARCH METHODS}

This research was conducted at regional apparatus organizations in Bantul Regency. The research subjects were local government employees in Bantul Regency, which comprised several agencies, offices, and sub-districts. This research data was quantitative data with a primary data type, obtained directly from the original source. Meanwhile, this research instrument was a questionnaire comprising several questions regarding work motivation, compensation, job satisfaction, and employee performance.

The sampling technique employed was convenience sampling. There were no specific criteria for sampling in this study. Samples were obtained from employees who were willing to fill out questionnaires for the research sample. The data collection technique in this study was by disseminating questionnaires to employees working in regional apparatus organizations in Bantul Regency. Respondents chose the disagreement and agreement level with the questions given. The measurement scale used in this questionnaire was a Likert scale model of 1 to 5 , ranging from strongly disagree (1), disagree (2), neutral (3), agree (4), and strongly agree (5). The research data were then processed utilizing IBM SPSS Statistics 20

\section{RESULTS AND DISCUSSION}

In this study, the number of questionnaires distributed in regional apparatus organizations in Bantul Regency was 135 questionnaires, while the number of returned questionnaires was 121 , and only 120 questionnaires could be processed.

Table 1. Validity Test Results

\begin{tabular}{|c|c|c|c|}
\hline No & $\begin{array}{c}\text { Question } \\
\text { Items }\end{array}$ & $\begin{array}{c}\text { Factor } \\
\text { Loading }\end{array}$ & Description \\
\hline 1 & MK 1 & 0.803 & Valid \\
\hline 2 & MK 2 & 0.771 & Valid \\
\hline 3 & MK 3 & 0.726 & Valid \\
\hline 4 & MK 4 & 0.583 & Valid \\
\hline 5 & MK 5 & 0.544 & Valid \\
\hline 6 & MK 6 & 0.594 & Valid \\
\hline 7 & K 1 & 0.570 & Valid \\
\hline 8 & K 2 & 0.770 & Valid \\
\hline 9 & K 3 & 0.583 & Valid \\
\hline 10 & K 4 & 0.743 & Valid \\
\hline 11 & K 5 & 0.729 & Valid \\
\hline 12 & K 6 & 0.768 & Valid \\
\hline 13 & KP 1 & 0.742 & Valid \\
\hline 14 & KP 2 & 0.791 & Valid \\
\hline 15 & KP 3 & 0.737 & Valid \\
\hline 16 & KP 4 & 0.784 & Valid \\
\hline 17 & KP 5 & 0.729 & Valid \\
\hline 18 & KP 6 & 0.712 & Valid \\
\hline 19 & KK 1 & 0.709 & Valid \\
\hline 20 & KK 2 & 0.794 & Valid \\
\hline 21 & KK 3 & 0.820 & Valid \\
\hline 22 & KK 4 & 0.583 & Valid \\
\hline 23 & KK 5 & 0.632 & Valid \\
\hline 24 & KK 6 & 0.755 & \\
\hline
\end{tabular}

Source: Output SPSS v.20, 2020
Based on the table above, all the questions used in the questionnaire were valid. All question items in the variable were significant at the $5 \%$ level. Thus, no question items were deleted, and all question items could be used in the entire test model.

Table 2. Reliability Test Results

\begin{tabular}{|l|l|c|l|}
\hline No & \multicolumn{1}{|c|}{ Variable } & $\begin{array}{c}\text { Cronbach's } \\
\text { Alpha Value }\end{array}$ & Description \\
\hline 1 & Work motivation & 0.736 & Reliable \\
\hline 2 & Compensation & 0.775 & Reliable \\
\hline 3 & $\begin{array}{l}\text { Employee } \\
\text { Performance }\end{array}$ & 0.805 & Reliable \\
\hline 4 & Job satisfaction & 0.842 & Reliable \\
\hline
\end{tabular}

Source: Output SPSS v.20, 2020

Based on the results from the table above, the entire values of Cronbach's Alpha in each variable were more than 0.7. Therefore, it could be concluded that all the instruments were reliable and could be employed for further research.

Table 3. One-Sample Kolmogorov-Smirnov Normality Test Results for Regression Test I

\begin{tabular}{|l|l|r|}
\hline \multicolumn{2}{|l|}{} & \multicolumn{2}{|c|}{$\begin{array}{c}\text { Unstandardized } \\
\text { Residual }\end{array}$} \\
\hline $\mathrm{N}$ & 120 \\
\hline Normal Parameters (a, b) & Mean & $0 \mathrm{E}-7$ \\
\cline { 2 - 3 } & $\begin{array}{l}\text { Std. } \\
\text { Deviation }\end{array}$ & 2.214 \\
\hline \multirow{2}{*}{$\begin{array}{l}\text { Most Extreme } \\
\text { Differences }\end{array}$} & Absolute & .131 \\
\cline { 2 - 3 } & Positive & .087 \\
\cline { 2 - 3 } & Negative & -.131 \\
\hline Kolmogorov-Smirnov Z & & 1.435 \\
\hline Asymp. Sig. (2-tailed) & & .132 \\
\hline
\end{tabular}

Source: Output SPSS v.20, 2020

The results from the table above show that the Asymp. Sig value in regression I was more than 0.05 . Therefore, it could be denoted that the data used in this study were normally distributed.

Table 4. One-Sample Kolmogorov-Smirnov Normality Test Results for Regression Test II

\begin{tabular}{|l|l|r|}
\hline \multicolumn{2}{|l|}{} & \multicolumn{2}{|c|}{$\begin{array}{c}\text { Unstandardized } \\
\text { Residual }\end{array}$} \\
\hline $\mathrm{N}$ & 120 \\
\hline Normal Parameters (a, b) & Mean & $0 \mathrm{E}-7$ \\
\cline { 2 - 3 } & $\begin{array}{l}\text { Std. } \\
\text { Deviation }\end{array}$ & 2.214 \\
\hline $\begin{array}{l}\text { Most Extreme } \\
\text { Differences }\end{array}$ & Absolute & .131 \\
\cline { 2 - 3 } & Positive & .087 \\
\cline { 2 - 3 } & Negative & -.131 \\
\hline Kolmogorov-Smirnov Z & & 1.435 \\
\hline Asymp. Sig. (2-tailed) & & .132 \\
\hline
\end{tabular}

Source: Output SPSS v.20, 2020 
The results above exhibit that the Asymp. Sig value in regression II was more than 0.05 . Hence, it could be inferred that the data used in this study were normally distributed.

Table 5. Multicollinearity Results for Regression Test I

\begin{tabular}{|c|c|c|c|}
\hline \multirow{2}{*}{$\begin{array}{c}\text { Independen } \\
\text { t Variable }\end{array}$} & \multicolumn{2}{|c|}{ Collinearity Statistics } & \multirow{2}{*}{ Description } \\
\hline & Tolerance & VIF & \\
\hline $\begin{array}{l}\text { Work } \\
\text { motivation } \\
\text { (X1) }\end{array}$ & .751 & 1.331 & $\begin{array}{l}\text { There is no } \\
\text { multicollinearity. }\end{array}$ \\
\hline $\begin{array}{l}\text { Compensati } \\
\text { on (X2) }\end{array}$ & .751 & 1.331 & $\begin{array}{l}\text { There is no } \\
\text { multicollinearity. }\end{array}$ \\
\hline
\end{tabular}

Source: Output SPSS v.20, 2020

Based on the multicollinearity results for regression test I, it could be seen that the tolerance values, both for work motivation and compensation variables, were 0.751 , more than 0.1. Besides, the VIF values for work motivation and compensation variables were 1.331 , less than 10 . Thus, it could be concluded that there was no multicollinearity.

Table 6. Multicollinearity Results for Regression Test II

\begin{tabular}{|l|c|c|l|}
\hline \multirow{2}{*}{$\begin{array}{l}\text { Independent } \\
\text { Variable }\end{array}$} & \multicolumn{2}{|c|}{$\begin{array}{c}\text { Collinearity } \\
\text { Statistics }\end{array}$} & \multicolumn{2}{c|}{ Description } \\
\cline { 2 - 4 } & Tolerance & VIF & \\
\hline $\begin{array}{l}\text { Work } \\
\text { motivation } \\
(\mathrm{X} 1)\end{array}$ & .659 & 1.518 & $\begin{array}{l}\text { There is no } \\
\text { multicollinearity. }\end{array}$ \\
\hline $\begin{array}{l}\text { Compensation } \\
(\mathrm{X} 2)\end{array}$ & .524 & 1.909 & $\begin{array}{l}\text { There is no } \\
\text { multicollinearity. }\end{array}$ \\
\hline $\begin{array}{l}\text { Job } \\
\text { satisfaction } \\
(\mathrm{Z})\end{array}$ & .478 & 2.093 & $\begin{array}{l}\text { There is no } \\
\text { multicollinearity. }\end{array}$ \\
\hline
\end{tabular}

Source: Output SPSS v.20, 2020

Based on the multicollinearity results for regression test II, the work motivation variable's tolerance value was 0.659 , with a VIF value of 1.518; the compensation variable had a tolerance value of 0.524 , with a VIF value of 1.909 ; the job satisfaction variable had a tolerance value of 0.478 , with a VIF value of 2.093. They were more than 0.1 , or the VIF values were less than 10 , which could be concluded that there was no multicollinearity.

Table 7. Heteroscedasticity Results for Regression Test I

\begin{tabular}{|c|c|c|}
\hline Variable & Sig. Value & Description \\
\hline $\begin{array}{l}\text { Work motivation } \\
\text { (X1) }\end{array}$ & .779 & $\begin{array}{l}\text { There is no } \\
\text { heteroscedasticity. }\end{array}$ \\
\hline Compensation (X2) & .855 & $\begin{array}{l}\text { There is no } \\
\text { heteroscedasticity. }\end{array}$ \\
\hline
\end{tabular}

Source: Output SPSS v.20, 2020

From the table above, the significance value was 0.779 for the work motivation variable and 0.855 for the compensation variable, more than alpha of 0.05 . Hence, it could be concluded that there was no heteroscedasticity.
Table 8. Heteroscedasticity Results for Regression Test I

\begin{tabular}{|l|c|l|}
\hline \multicolumn{1}{|c|}{ Variable } & Sig. Value & \multicolumn{1}{|c|}{ Description } \\
\hline $\begin{array}{l}\text { Work motivation } \\
(\mathrm{X} 1)\end{array}$ & .086 & $\begin{array}{l}\text { There is no } \\
\text { heteroscedasticity. }\end{array}$ \\
\hline Compensation (X2) & .836 & $\begin{array}{l}\text { There is no } \\
\text { heteroscedasticity. }\end{array}$ \\
\hline Job satisfaction (Z) & .455 & $\begin{array}{l}\text { There is no } \\
\text { heteroscedasticity. }\end{array}$ \\
\hline
\end{tabular}

Source: Output SPSS v.20, 2020

Seen from the table above, the significance value was 0.086 for the work motivation variable, 0.836 for the compensation variable, and 0.455 for the job satisfaction variable, which was more than the alpha of 0.05 . Thus, it could be concluded that this second regression model did not contain heteroscedasticity.

Table 9. Coefficient of Determination Test $\left(\mathrm{R}^{2}\right)$ Results I

\begin{tabular}{|c|c|c|c|c|}
\hline Model & $\mathbf{R}$ & $\begin{array}{c}\mathbf{R} \\
\text { Square }\end{array}$ & $\begin{array}{c}\text { Adjusted } \\
\mathbf{R} \\
\text { Square }\end{array}$ & $\begin{array}{c}\text { Std. Error } \\
\text { of the } \\
\text { Estimate }\end{array}$ \\
\hline 1 & $.723(\mathrm{a})$ & .522 & .514 & 2.065 \\
\hline
\end{tabular}

Source: Output SPSS v.20, 2020

Based on the table above, on the results of the regression determination coefficient test for substructure I, the adjusted $\mathrm{R}$ square value was 0.514 . It indicated that the independent variables of work motivation and compensation could explain the intervening variable of job satisfaction by $51.4 \%$, while the remaining $48.6 \%$ was influenced by other variables not examined.

Table 10. Coefficient of Determination Test $\left(\mathrm{R}^{2}\right)$ Results II

\begin{tabular}{|c|c|c|c|c|}
\hline Model & $\mathbf{R}$ & $\begin{array}{c}\mathbf{R} \\
\text { Square }\end{array}$ & $\begin{array}{c}\text { Adjusted } \\
\mathbf{R} \\
\text { Square }\end{array}$ & $\begin{array}{c}\text { Std. Error } \\
\text { of the } \\
\text { Estimate }\end{array}$ \\
\hline 1 & $.439(\mathrm{a})$ & .193 & .172 & 2.243 \\
\hline
\end{tabular}

Source: Output SPSS v.20, 2020

The table above shows the results of the regression determination coefficient test for substructure II, where it was known that the adjusted $\mathrm{R}$ square value was 0.193 . It signified that the independent variables of work motivation, compensation, and job satisfaction could explain the dependent variable of local government employee performance by $17.2 \%$, while the remaining $82.8 \%$ was explained by other variables not examined.

Table 11. F I Test Results

\begin{tabular}{|c|c|c|c|c|c|}
\hline Model & $\begin{array}{l}\text { Sum of } \\
\text { Square }\end{array}$ & Df & $\begin{array}{c}\text { Mean } \\
\text { Square }\end{array}$ & $\mathbf{F}$ & Sig. \\
\hline $\begin{array}{l}1 \\
\text { Regression }\end{array}$ & 545.136 & 2 & 272.568 & 63.936 & 0.000 \\
\hline Residual & 498.789 & 117 & 4.263 & & \\
\hline
\end{tabular}


\begin{tabular}{|c|c|c|c|c|c|} 
Total & 104.93 & 119 & & & \\
\hline
\end{tabular} in results was $0.000<$ alpha 0.05 . Thus, it could be denoted that there was a significant simultaneous effect of compensation and work motivation on job satisfaction.

Table 12. F II Test Results

\begin{tabular}{|l|c|c|c|c|c|}
\hline \multicolumn{1}{|c|}{ Model } & $\begin{array}{c}\text { Sum of } \\
\text { Square }\end{array}$ & Df & $\begin{array}{c}\text { Mean } \\
\text { Square }\end{array}$ & F & Sig. \\
\hline 1 & 139.284 & 3 & 46.428 & 9.230 & 0.000 \\
Regression & & & & & \\
\hline Residual & 583.516 & 116 & 5.030 & & \\
\hline Total & 722.800 & 119 & & & \\
\hline
\end{tabular}

Source: Output SPSS v.20, 2020

The test results in the table above reveal that the second regression result was $0.000<$ alpha 0.05 . Therefore, it could be inferred that there was a significant simultaneous influence of compensation, work motivation, and job satisfaction on employee performance.

Table 13. T-Test Results I

\begin{tabular}{|c|l|c|c|c|c|c|}
\hline \multirow{2}{*}{ Model } & \multicolumn{2}{|c|}{$\begin{array}{c}\text { Unstandardi } \\
\text { zed } \\
\text { Coefficients }\end{array}$} & $\begin{array}{c}\text { Standardi } \\
\text { zed } \\
\text { Coefficie } \\
\text { nts }\end{array}$ & \multirow{2}{*}{ t } & Sig. \\
\cline { 3 - 5 } & B & $\begin{array}{c}\text { Std. } \\
\text { Erro } \\
\text { r }\end{array}$ & Beta & & \\
\hline 1 & (Constant) & $\begin{array}{c}4.70 \\
7\end{array}$ & 1.773 & & 2.6 & 0.0 \\
& .322 & .080 & .299 & 4.0 & 0.0 \\
& $\begin{array}{l}\text { Work } \\
\text { motivation } \\
\text { (X1) }\end{array}$ & & & & 51 & 00 \\
\hline & $\begin{array}{l}\text { Compensa } \\
\text { tion (X2) }\end{array}$ & .502 & .070 & .526 & 7.1 & 0.0 \\
& & & & 32 & 00 \\
\hline
\end{tabular}

Source: Output SPSS v.20, 2020

From the table above, the significance value for work motivation and compensation variables was 0.000 , where both < alpha 0.05 . It indicated that the independent variables of work motivation and compensation affected the intervening variable of job satisfaction. Hence, it could be denoted that the regression equation in this study is:

$$
\mathrm{Z}=4.707+0.299 \mathrm{X} 1+0.526 \mathrm{X} 2+\mathrm{e}
$$

Table 14 T-Test Results II

\begin{tabular}{|c|c|c|c|c|c|c|}
\hline \multirow{2}{*}{ Model } & \multicolumn{2}{|c|}{$\begin{array}{c}\text { Unstandardi } \\
\text { zed } \\
\text { Coefficients }\end{array}$} & $\begin{array}{c}\text { Standardi } \\
\text { zed } \\
\text { Coefficie } \\
\text { nts }\end{array}$ & \multirow{2}{*}{ t } & Sig. \\
\cline { 3 - 7 } & & B & $\begin{array}{c}\text { Std. } \\
\text { Erro } \\
\text { r }\end{array}$ & Beta & & \\
\hline 1 & (Constant) & $\begin{array}{c}14.26 \\
4\end{array}$ & $\begin{array}{c}1.98 \\
3\end{array}$ & & 7.1 & 0.0 \\
& & & & 92 & 00 \\
\hline
\end{tabular}

\begin{tabular}{|l|l|c|c|c|c|c|}
\hline $\begin{array}{l}\text { Work } \\
\text { motivation } \\
\text { (X1) }\end{array}$ & .245 & .092 & .273 & 2.6 & 0.0 \\
& & & & 61 & 09 \\
\hline Compensa & -.084 & .092 & -.105 & - & 0.3 \\
tion (X2) & & & & .91 & 63 \\
& & & & 2 & \\
\hline & Job & .345 & .100 & .295 & 2.4 & 0.0 \\
satisfactio & & & & 43 & 16 \\
$\mathrm{n}(\mathrm{Z})$ & & & & & \\
\hline
\end{tabular}

Source: Output SPSS v.20, 2020

The multiple regression results for substructure 2 in the table above show that the significance value was 0.009 for the work motivation variable, 0.363 for the compensation variable, and 0.016 for the job satisfaction variable. It signified that the variables of work motivation and job satisfaction affected the dependent variable of the performance of local government employees because they had a significance value of $<$ alpha 0.05 . Meanwhile, the compensation variable did not affect the dependent variable of the performance of local government employees because it had a significance value of $>0.05$ alpha.

Based on the table above, the regression equation in this study could be concluded as follows:

$$
\mathrm{Y}=14.264+0.273 \mathrm{X} 1+(-0.105) \mathrm{X} 2+0.295 Z+e
$$

Based on the research test results above, the work motivation variable had a significance value of $0.009<$ alpha 0.05 and a regression coefficient value of 0.273 . The work motivation variable had a t-count value of 2.661 , with a t-table of 2.358; t-count > t-table. Thus, it could be concluded that the variable $\mathrm{X} 1$ had a direct relationship with $\mathrm{Y}$. It could also be denoted that work motivation had a positive effect on the performance of local government employees. It aligns with research carried out by Nugroho et al. (2017), which found that motivation had a major influence on employee performance at PT Bank Danamon, SEMM Division Ngawi Area. It indicates that the higher the motivation, the higher the employee's performance, causing the employee to be well motivated and show a better performance.

From the test results, the compensation variable had a significance value of $0.363>$ alpha 0.05 and a regression coefficient value of 0.105 . In addition, the compensation variable had a t-count value of 0.912 , with a t-table of 2.358 ; $\mathrm{t}$-count $<\mathrm{t}$-table. Therefore, it could be inferred that the X2 variable was rejected. In other words, compensation did not affect the performance of local government employees. It was because the compensation in the form of allowances and incentives provided by the agency has not been felt to be fair to employees and was not in accordance with the employees' expectations in local government. This study's results are supported by a study carried out by Murty \& Hudiwinarsih (2012) that compensation had an effect but was not significant on employee performance.

The results of testing the third hypothesis had a t-count value of $2.443>$ t-table of 2.358 and a significance value of 0.016 < alpha of 0.05 . It could be interpreted that job satisfaction affected the performance of local government 
employees. Ilahi et al. (2017) stated that job satisfaction positively impacted employee performance. It showed that employees with high job satisfaction would have an impact on increasing their performance. A study by Sukidi \& Wajdi (2017) also affirmed that job satisfaction positively affected employee performance. It is shown that job satisfaction is a factor affecting employee performance. If job satisfaction is high, it can also improve employee performance. Job satisfaction here is the condition felt by a worker doing his job, which describes whether he is happy or not working in an organization.

Furthermore, for the fourth hypothesis, two conditions should be met:

1. Hypotheses 1 and 3 had to be accepted.

2. The total indirect effect was higher than the total direct influence.

Based on these conditions and seen from the t-value test results presented in the previous table, the first condition was fulfilled. Meanwhile, it was not met for the second condition because the indirect effect was 0.088 < the direct effect of 0.273; thus, the fourth hypothesis was rejected. Therefore, it could be denoted that work motivation did not affect the performance of local government employees through job satisfaction.

For the fifth hypothesis, two conditions should also be met for it to be accepted:

1. Hypotheses 2 and 3 had to be accepted.

2. The total indirect effect was higher than the total direct influence.

Judging from the $t$-value test results displayed in the previous table, the first condition could be declared not fulfilled because only one of the hypotheses was accepted, namely the third hypothesis. Meanwhile, it could be met for the second condition because of the indirect effect with a value of $0.155>$ direct effect with a value of 0.105 . It showed that the fifth hypothesis concluded that compensation did not affect the performance of local government employees through job satisfaction.

\section{CONCLUSION}

This study aimed to test and prove empirically about work motivation, compensation, and job satisfaction on the performance of local government employees in Bantul Regency. The samples in this study were 27 regional apparatus organizations in Bantul Regency, covering several agencies, offices, and sub-districts. The conclusions obtained from this study are: (1) Work motivation had a positive and significant influence on the performance of local government employees. (2) Compensation did not affect the performance of local government employees. (3) Job satisfaction had a positive and significant effect on the performance of local government employees. (4) Work motivation did not affect the performance of local government employees mediated by job satisfaction. (5) Compensation did not affect the performance of local government employees mediated by job satisfaction.

However, this study has limitations. The research object used in this study was only carried out at regional apparatus organizations in Bantul Regency. In addition, not all regional apparatus organizations allowed research to be conducted due to the COVID-19 pandemic.

\section{REFERENCES}

[1] Achmad, T. 2014. Menjadikan Konsultan Pajak sebagai Agents of Tax Compliance. Website: http://www. pajak.go.id/ content/article/ menjadikan-konsultanpajak-sebagai-agents-tax-compliance

[2] Amarullah, A. 2010. 13 Konsultan Pajak di Surabaya Ditahan. Website: http:// nasional.news.viva. co.id/news/read/148362-13_konsultan_pajak_ di_surabaya_ditahan

[3] Anton. 2012. Analisis Persepsi Akuntan Publik dan Mahasiswa Akuntansi terhadap Kode Etik Ikatan Akuntan Indonesia (Studi Kasus pada Beberapa Universitas serta Beberapa Kantor Akuntan Publik di Semarang). Makalah Ilmiah INFORMATIKA, 3 (2), 134.

[4] Arif, M. L. S., R. Aulia dan N. Herawati. 2014. Bagaimanakah Persepsi Mahasiswa Akuntansi tentang Praktik Akuntansi Kreatif Ditinjau dari Teori Etika Bisnis?. Jurnal Akuntansi Multiaparadigma, 5 (1), 96112.

[5] Ayundasari, D. Y., Sudiro, A., \& Irawanto, D. W. (2017). Improving Employee Performance Through Work Motivation and Self-Efficacy Mediated By Job Satisfaction. Jurnal Aplikasi Manajemen, 15(4), 587599. https://doi.org/10.21776/ub.jam2017.015.04.05

[6] Beritasatu. 2012. Konsultan Pajak Jadi Tersangka Baru Kasus Dhana Widyatmika. Website: http://www. beritasatu.com/nasional/57766-konsultan-pajak-jaditersangka-baru-kasus-dhana-widyatmika.html

[7] Blanthorne, C., H. A. Burton dan Fisher, D. 2014. The Aggressiveness of Tax Professional Reporting: Examining the Influence of Moral Reasoning. Advances in Accounting Beha-vioral Research, 16, 149 - 181.

[8] Bobek, D. D., A. M. Hageman dan R. R. Radtke. 2010. The Ethical Environment of Tax Professionals: Partner dan Non-Partner Per-ceptions dan Experiences. Journal of Business Ethics, 92 (4), 637-654.

[9] Dessler, G. (2017). Manajemen Sumber Daya Manusia. In Pelatihan dan Pengembangan. https://doi.org/10.1145/2505515.2507827

[10] Dharma, Y. (2018). The Effect of Work Motivation on the Employee Performance with Organization Citizenship Behavior as Intervening Variable at Bank Aceh Syariah. https://doi.org/10.1108/978-1-78756793-1-00065

[11] Fachreza, Musnadi, S., \& Majid, M. S. A. (2018). Pengaruh Motivasi kerja, lingkungan kerja, dan budaya organisasi terhadap kinerja karyawan dan dampaknya pada kinerja Bank Aceh Syariah di Kota Banda Aceh. Jurnal Magister Manajemen.

[12] Fernanda, R., \& Sagoro, E. M. (2016). Pengaruh Kompensasi, Kepuasan Kerja, Motivasi Kerja Dan Gaya Kepemimpinan Terhadap Kinerja Karyawan. Nominal, Barometer Riset Akuntansi Dan Manajemen. https://doi.org/10.21831/nominal.v5i2.11727

[13] Handoko, T. H. (2011). Manajemen Personalia dan Sumber Daya Manusia. Pengantar Manajemen.

[14] Hidayah, N., \& Aisyah, M. N. (2016). Pengaruh Kompensasi Terhadap Kinerja Karyawan Dengan 
Kepuasan Kerja Sebagai Variabel Interveninng (Studi Kasus Pada Karyawan Bagian Keuangan dan Akuntansi PT. Omega Yogyakarta). Jurnal Profita.

[15] Husein, N. M., \& Hanifah, H. (2019). The Effect of Job Satisfaction on Employee Performance Through Coaching as Intervening Variables in Banjarmasin Government. 64, 830-836. https://doi.org/10.2991/piceeba2-18.2019.72

[16] Ilahi, D., Mukzam, M., \& Prasetya, A. (2017). Pengaruh Kepuasan Kerja Terhadap Disiplin Kerja Dan Komitmen Organisasional (Studi Pada Karyawan PT.PLN (Persero) Distribusi Jawa Timur Area Malang). Jurnal Administrasi Bisnis S1 Universitas Brawijaya.

[17] Kurniawan, M. (2013). Pengaruh Komitmen Organisasi, Budaya Organisasi dan Kepuasan Kerja Terhadap Kinerja Organisasi Publik (Studi Empiris pada SKPD Pemerintah Kabupaten Kerinci). Skripsi FE Universitas Negeri

Padang. https://doi.org/10.1073/pnas.0703993104

[18] Locke, E. A. (1976). The nature and causes of job satisfaction. In Handbook of Industrial and Organizational Psychology.

[19] Mangkunegara, A. A. A. P. (2003). Manajemen Sumber Daya Manusia Perusahaan. In Remaja Rosdakarya. https://doi.org/10.1038/cddis.2011.1

[20] Martini, I. A. O., \& Sarmawa, I. W. G. (2019). The Role of the Employee Work Motivation in Mediating the Work Culture towards Their Performance. Jurnal Ekonomi Dan Bisnis Jagaditha, 6(1), 15-21.

[21] Murty, W. A., \& Hudiwinarsih, G. (2012). Pengaruh Kompensasi, Motivasi dan Komitmen Organisasional Terhadap Kinerja Karyawan Bagian Akuntasi. Akuntasi.

[22] Nugroho, F. A., . M., \& . M. (2017). Pengaruh Budaya Organisasi, Kepemimpinan Dan Motivasi Kerja Terhadap Kinerja Karyawan Pada Pt Bank Danamon Divisi Semm Area Ngawi. Ekuilibrium : Jurnal Ilmiah Bidang Ilmu Ekonomi. https://doi.org/10.24269/ekuilibrium.v12i2.674

[23] Pancasila, I., Haryono, S., \& Sulistyo, B. A. (2020). Effects of work motivation and leadership toward work satisfaction and employee performance: Evidence from Indonesia. Journal of Asian Finance, Economics and Business.

https://doi.org/10.13106/jafeb.2020.vol7.no6.387

[24] Prabowo, T. S., Noermijati, N., \& Irawanto, D. W. (2018). The Influence Of Transformational Leadership And Work Motivation On Employee Performance Mediated By Job Satisfaction. Jurnal Aplikasi Manajemen.

https://doi.org/10.21776/ub.jam.2018.016.01.20

[25] Primananda, N., \& Djastuti, I. (2015). Pengaruh Disiplin Kerja, Budaya Organisasi Dan Lingkungan Kerja
Terhadap Kinerja Pegawai Sekretariat Daerah Pekalongan. Diponegoro Journal of Management.

[26] Putrana, Y., Fathoni, A., \& Warso, M. M. (2016) Pengaruh Kepuasan Kerja Dan Komitmen OrganisasiTerhadap Organizational Citizenship Behavior Dalam Meningkatkan Kinerja Karyawan Pada Pt . Gelora Persada Mediatama Semarang. Journal of Management.

[27] Ramli, A. H. (2019). Compensation, Job Satisfaction and Employee Performance in Health Services. Business and Entrepreneurial Review, 18(2), 177. https://doi.org/10.25105/ber.v18i2.5335

[28] Sidanti, H. (2015). Pengaruh lingkungan kerja, disiplin kerja dan motivasi kerja terhadap kinerja pegawai negeri sipil di sekretariat dprd kabupaten madiun. Jurnal JIBEKA.

[29] Stringer, C., Didham, J., \& Theivananthampillai, P. (2011). Motivation, pay satisfaction, and job satisfaction of front-line employees. Qualitative Research in Accounting and Management. https://doi.org/10.1108/11766091111137564

[30] Suharto, A. A. (2012). Pengaruh Kualitas Sumber Daya Manusia, KOmitmen Dan MOtivasi Terhadap Kinerja Pegawai Pada inspektorat kabupaten kediri. Ilmu Manajemen.

[31] Sukidi, S., \& Wajdi, F. (2017). Pengaruh Motivasi, Kompensasi, Dan Kepuasan Kerja Terhadap Kinerja Pegawai Dengan Kepuasan Kerja Sebagai Variabel Intervening. Jurnal Manajemen Dayasaing, 18(2), 79. https://doi.org/10.23917/dayasaing.v18i2.4505

[32] Sumiati, S. S. (2018). Effect of Compensation, Communication and Spirituality At Work on the Performance of the Turnover Intention As an Intervening Variable. Archives of Business Research, 6(10), 368-378. https://doi.org/10.14738/abr.610.5413

[33] Supiyanto, Y. (2015). Pengaruh Kompensasi, Kompetensi Dan Komitmen Organisasional Terhadap Kepuasan Dan Kinerja. Jurnal Economia. https://doi.org/10.21831/economia.v11i2.8281

[34] Suwardi, S., \& Utomo, J. (2011). Pengaruh Motivasi Kerja, Kepuasan Kerja, Dan Komitmen Organisasional Terhadap Kinerja Pegawai (Studi Pada Pegawai Setda Kabupaten Pati). Jurnal Analisis Manajemen.

[35] Widyantara, I., \& Ardana, I. (2015). Pengaruh Kepuasan Kerja Dan Komitmen Organisasi Terhadap Intensitas Turnover Karyawan. E-Jurnal Manajemen Universitas Udayana.

[36] Yanuarti, E., \& W, A. S. (2014). Pengaruh Gaya Kepemimpinan, Kepuasan Kerja Dan Komitmen Organisasi Terhadap Kinerja Guru. Universitas Muhammadiyah Yogyakarta. 